\title{
Isolation and Identification of the most Common Bacteria Isolated from Intestine of Broiler Chickens in Egypt
}

\author{
Eman M. Desouky ${ }^{1}$, Heba N. Deif*2 and Jakeen K. Eljakee ${ }^{2}$ \\ ${ }^{1}$ Master student at Department of Microbiology, Faculty of Veterinary Medicine, Cairo University, Egypt. \\ ${ }^{2}$ Department of Microbiology, Faculty of Veterinary Medicine, Cairo University, Egypt. \\ *Corresponding Author, Heba N. Deif, E-Mail: naim_heba@yahoo.com
}

\begin{abstract}
Bacteria are seriously affecting broiler chickens and the poultry industry in many countries, as well as in Egypt. Both pathogenic and nonpathogenic bacterial species have been reported in broiler chickens. The present study aimed to isolate and identify the most common bacteria recovered from apparently healthy broiler chickens by conventional methods and the VITEK system. Samples were taken from 30 broiler chickens of different ages ( $3-5$ weeks) from different retail markets in Cairo during the period from January to August 2019. Bacteriological examination of the samples showed both Gram-positive and Gram-negative bacteria as well. Lysinibacillus sphaericus $(\mathrm{n}=7)$, Escherichia coli $(\mathrm{n}=5)$, Proteus species $(\mathrm{n}=4)$, Bacillus cereus $(\mathrm{n}=3)$, with isolation rates of $23.3 \%, 16.6 \%$, $13.3 \%$ and $10 \%$, were identified. In addition to its pathogenicity and hazardous action, some strains of Lysinibacillus sphaericus have a larvicide effect on some species of mosquitoes. So, further studies and investigations will be conducted to test Lysinibacillus sphaericus and Bacillus cereus isolates for their biological control activity and/or their potency to remove, control, or reduce petroleum hydrocarbon soil contaminants in different localities. It will be used as an alternative control agent for numerous synthetic commercial formulations.
\end{abstract}

Keywords: Bacillus cereus, Broilers, E.coli, Intestine, Lysinibacillus sphaericus, Proteus species, VITEK.

\author{
Original Article: \\ DOI:https://dx.doi.org/10.21608/javs \\ .2021.87134.1092
}

\author{
Received :23 July, 2021. \\ Accepted :23 August, 2021. \\ Published in October, 2021.
}

This is an open access article under the term the Creative Commons Attribution 4.0 (CC-B International License . To view a copy of t license, visit:

http://creativecommons.org/licenses/by/4.0/

\section{INTRODUCTION}

The intestines of both healthy and diseased chickens serve as a reservoir for both pathogenic and nonpathogenic bacteria (Clavijo and Florez, 2018). The gastrointestinal compartments of chickens are densely populated with complex microbial communities dominated by Bacteria (Wei et al., 2013).

Enterobacteriaceae is a family of rod-shaped, aerobic, facultative anaerobic bacteria. E. coli belongs to this family, found in humans and other animals commonly in their large intestines (Campbell $\boldsymbol{e t}$ al., 2002). It can be commensal or pathogenic and cause diseases to its host (Salyers and Whitt, 2002). Although it is found in lower numbers than other major commensals, E. coli is considered the most common internal bacteria causing diseases may be due to carrying several virulence factors (Stecher and Hardt, 2008).
Fires, affecting many countries worldwide, are found to cause losses of soil nutrients and infertility. Lysinibacillus sphaericus, a Gram-positive, spore-forming Bacilli, isolated from soil and water (Martínez and Dussán, 2017) and reported to have a very important role in improving the soil quality which helps the replantation processes. Consequently, $L$. sphaericus could be used as a good nutrient enhancer for plant growth in fire-impacted soils (AguirreMonroy et al., 2019).

Bacillus cereus is a novel emerging pathogen contaminated extensively in animal feed and food chains, posing a huge economic loss for the animal industry and a high risk for human health (Haque $\boldsymbol{e t}$ al., 2021). It is distributed in the environment but can also colonize human and invertebrate intestines (Jensen et al., 2003). Biochemical testing of B. cereus shows its ability to generate acid from glucose but not from mannitol, xylose, and arabinose; oxidase negative, motility positive, catalase-positive, citrate 
utilization positive, casein hydrolysis positive, nitrate reduction positive, Voges-Proskauer (VP) reaction positive, 1-tyrosine reduction positive, and growth in $0.001 \%$ lysozyme positive (Adams and Moss, 2005). Bacillus cereus may cause two different and distinct forms of food-borne diseases: the emetic (vomiting) and diarrheal types (Forghani et al., 2014).

Various species of Proteus, which mainly exist as saprophytes, are known to cause septic infections in humans (Wilson and Miles, 1975) and animals (Pine et al., 1973; O'Driscoll, 1977) under certain conditions. Here, we describe the isolation and identification of bacilli from apparently healthy broiler chickens.

\section{MATERIIALS AND METHODS}

\section{Samples Collection:}

Between January and August 2019, 30 intestinal samples were collected from broiler chickens purchased from the retail market in Cairo. The birds were sacrificed and their intestines were collected for the bacteriological examination which was carried out in the Microbiology Department, Faculty of Veterinary Medicine, Cairo University, Egypt. Under complete aseptic conditions, each intestinal sample was placed in a sterile Petri dish and opened using sterile forceps. Intestinal contents were collected using sterile cotton swabs, then were inoculated on a selective medium.

\section{Isolation and Culture of Enterobacteriaceae:}

Each sample was grown on MacConkey agar medium at $37^{\circ} \mathrm{C}$ for $24 \mathrm{~h}$. Colonies appearing after $24 \mathrm{~h}$ were re-streaked to obtain a pure culture and then subjected to preliminary identification using microscopy, biochemical tests. Colonies representing each bacterial species were identified and characterized by using standard bacteriological methods according to the methods described by Barrow and Felthan (2004). The biochemical reagents and tests used included: Oxidase test, Triple sugar iron agar, PPA (Phenyl pyruvic acid), Urease, Simmons citrate, Indole, Methyl Red and Motility test was performed by referring to Bergey's Manual ( Holt et al., 1994 ) and the Manual for the Identification of Medical Bacteria (Barrow and Felthan, 2004)

\section{Isolation and culture of Gram-positive bacilli:}

Intestinal samples were cultured in buffered peptone-water (Oxoid). Aerobic spore-forming isolates were selected by heat (Nicholson and Setlow, 1990). Subsequent plating of buffered peptone-water was done aerobically on Difco nutrient agar. Unless otherwise stated, bacillus isolates were routinely grown aerobically at $37^{\circ} \mathrm{C}$ for $48 \mathrm{~h}$ on Difco nutrient agar. Identification of the pure isolates was made based on staining, colony morphology, cultural, physiological and biochemical characteristics of pure isolates by using standard bacteriological and biochemical procedures as described by Quinn et al., (2002). The catalase activity of bacterial isolates was detected by resuspension of a colony in a 3\% solution of hydrogen peroxide (Sigma). Hemolysis was determined on Columbia 5\% sheep blood agar plates (bioMérieux), streaked with colonies from fresh Difco nutrient agar plates. Readings were taken after incubation at $37^{\circ} \mathrm{C}$ for $24 \mathrm{~h}$.

\section{VITEK 2 COMPACT:}

The biochemical profile of test isolates was determined with the VITEK system- bioMérieux following the manufacturer's instructions. After overnight incubation at $37^{\circ} \mathrm{C}$, colonies showing different morphologies were picked up from each selective plate and tested separately with VITEK for identification.

\section{RESULTS}

\section{Isolation of Gram-negative bacteria:}

The results illustrate that Escherichia coli $(n=5)$ and Proteus species $(n=4)$ were identified from the examined samples.

\section{Isolation of spore-forming bacteria:}

Spore-forming bacteria were selected by the heat of chicken fecal material. Treated samples were subsequently plated and incubated aerobically. Microscopic examination of the isolates showed a diverse collection of rod-shaped bacteria producing endospores of different sizes and shapes, including those that caused swelling of the mother cell (Fig. 1). A bacteriological examination showed the isolation of 7 Lysinibacillus sphaericus isolates and 3 Bacillus cereus isolates. All the isolates were catalase-positive, a characteristic that differentiates Bacillus from the anaerobic spore-forming Clostridium spp. All Bacillus isolates presented some level of hemolysis on $5 \%$ sheep blood agar.

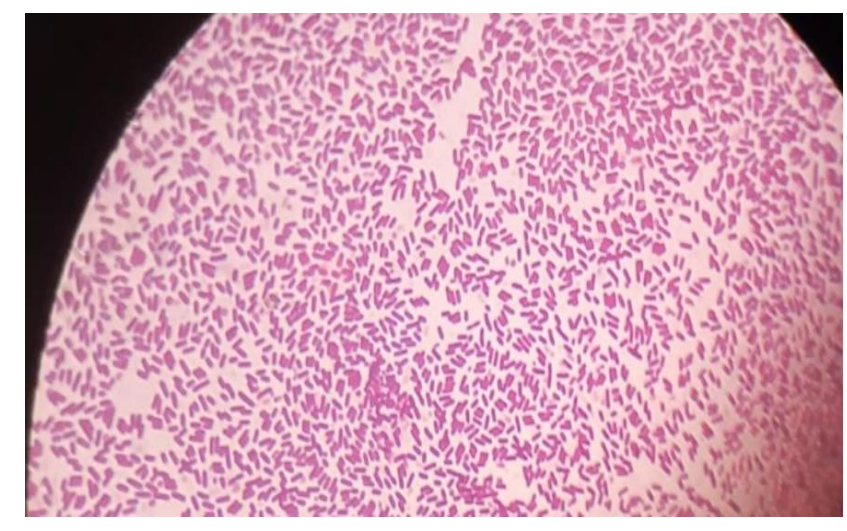

Fig. 1. Morphology of fecal bacilli isolated from broilers. 


\section{DISCUSSION}

A broiler is any chicken that is bred and raised specifically for meat production. The chicken gastrointestinal (GI) tract harbors complex communities of bacteria (Ranjitkar et al., 2016).

Bacteriological examination showed that Lysinibacillus sphaericus $(\mathrm{n}=7), \quad$ Escherichia coli $(\mathrm{n}=5)$, Proteus species $(\mathrm{n}=4)$, and Bacillus cereus $(\mathrm{n}=3)$, were identified with $23.3 \%, 16.6 \%, 13.3 \%$ and $10 \%$, respectively. Hossain et al., (2008) identified $22.86 \%$ E. coli isolates from broilers and $38.71 \%$ isolates from layers. From internal organs of broiler Roy et al., (2012) isolated Escherichia coli from 26 (52\%) samples; similarly, Salmonella spp., Staphylococcus spp., Bacillus spp., and Pasteurella spp. were isolated from 15 (30\%), 10 (20\%), 9 (18\%) and $4(8 \%)$ samples, respectively. Of the 235 strains out of 981 fecal swabs obtained by Dandachi et al., (2018) from poultry farms, 217 were identified as $E$. coli (92\%), eight as Klebsiella pneumoniae (3\%), three as Proteus mirabilis (1\%) and three as Enterobacter cloacae (1\%). Out of 140 chicken dropping samples collected by Bushen et al., (2021), 61 (43.6\%) showed bacterial growth. Of these, E. coli accounts for 39.0\%, followed by $K$. pneumoniae (22.0\%), P. mirabilis (19.3\%), and Salmonella species (17.7\%).

Recent studies have shown that spores of a laboratory strain of Bacillus decreased different aspects of colonization of young chicks by the avian colibacillosis agent Escherichia coli O78:K80, Salmonella enterica serotype Enteritidis, and Clostridium perfringens (Barbosa et al., 2005). Bacillus spores are being used as human and animal probiotics despite studies now indicating extensive mislabeling of constituent Bacillus strains (Green $\boldsymbol{e t}$ al., 1999, Hoa et al., 2000). Several of these strains have also been multidrug-resistant and harbor toxin genes (Hoa et al., 2000; Duc et al., 2004).

Therefore, it is becoming increasingly clear that a more rigorous selection process is required for Bacillus probiotic candidates. Our understanding of competitive exclusion and probiotic properties relates mainly to lactic acid bacteria; however, with relatively very little known regarding Bacillus spp. (Barbosa $\boldsymbol{e t}$ al., 2005). Nevertheless, it is anticipated that the competitive exclusion of pathogens by Bacillus probiotics will result from one or more modes of action, including immune exclusion, competition for adhesion sites, and production of antimicrobial agents, such as bacteriocins (Patterson and Burkholder, 2003).

Thus, in light of these arguments, we aimed in this study to isolate and identify the most common bacilli bacteria recovered from the gastrointestinal tract of apparently healthy broiler chickens by conventional methods and the VITEK system. The work described in this article identified 10 aerobic spore-forming bacilli (7 Lysinibacillus sphaericus and 3 Bacillus cereus).

Three Bacillus cereus isolates were detected from the examined samples. It is a facultatively anaerobic, toxin-producing Gram-positive bacterium that can be found in soil vegetation and even food. The pathogenicity of $B$. cereus, whether intestinal or nonintestinal, is intimately associated with the production of tissue-destructive exoenzymes. Among these secreted toxins are four hemolysins, three distinct phospholipases, an emesis-inducing toxin, and proteases (Hölzel et al., 2018; Nguyen and Tallent, 2019). The Centers for Disease Control (CDC) website states that, there were 619 confirmed outbreaks of Bacillus-related poisoning from 1998 through 2015, involving 7385 illnesses (Thein et al., 2010; May et al., 2016).

In the present study, 7 Lysinibacillus sphaericus isolates were identified. It is a Grampositive, mesophilic, rod-shaped bacterium commonly found in soil. The reclassification from Bacillus sphaericus to Lysinibacillus sphaericus is based on the fact that the Lysinibacillus genus, in contrast to the type species of the genus Bacillus, contains peptidoglycan with lysine, aspartic acid, alanine and glutamic acid (Iftikhar et al., 2007). It can form resistant endospores tolerant to high temperatures, chemicals, and ultraviolet light and can remain viable for long periods. It is of particular interest to the World Health Organization due to the larvicide effect of some strains against two mosquito genera, Culex and Anopheles (Colin, 2012) more effective than Bacillus thuringiensis, frequently used as a biological pest control.

Recent studies have shown that a laboratory strain of Bacillus could suppress poultry colonization by different avian pathogens (Barbosa et al., 2005).

\section{CONCLUSION}

Most Bacillus cereus strains produce toxins accused of causing food-borne illnesses. However, the antifungal compounds produced by some Bacillus cereus strains have been used as useful biological control agents in the suppression of fungi and crop disease. So, future studies should focus on the antibacterial activities of aerobic spore-forming bacilli.

\section{Declaration of Conflicting Interests}

The authors revealed that there was no potential conflicts of interest. 


\section{REFERENCES}

ADAMS, M. R. AND MOSS, M.O., 2005. Food Microbiology, $2^{\text {nd }}$ Edition. The Royal Society of Chemistry, Thomas Graham House, Science Park, Milton Road, Cambridge CB4 OWF, UK; pp: 187-190.

AGUIRRE-MONROY, A. M., SANTANA-MARTÍNEZ, J. C. AND DUSSÁN, J., 2019. Lysinibacillus sphaericus as a nutrient enhancer during fire-impacted soil replantation, Hindawi, Article ID 3075153. https://doi.org/10.1155/2019/3075153

BARBOSA, T. M., SERRA, C. R., LA RAGIONE R. M., WOODWARD M .J. AND HENRIQUES A.O., 2005. Screening for Bacillus isolates in the broiler gastrointestinal tract. Appl. Environ. Microbiol 71(2): 968-978.

BARROW, G. I. AND FELTHAN, R. K. A., 2004. Cowan and Steels identification of Medical bacteria. 4th Edition. Cambridge University Press 50-145.

BUSHEN, A., TEKALIGN, E. AND ABAYNEH, M., 2021. Drug- and Multidrug-Resistance Pattern of Enterobacteriaceae Isolated from Droppings of Healthy Chickens on a Poultry Farm in Southwest Ethiopia. Infection and Drug Resistance 14: 2051-2058.

CAMPBELL, N. A., REECE, J. B., 2002. Biology, Pearson Education Inc, San Francisco.

CLAVIJO, V. AND FLOREZ, M. J. V., 2018. The gastrointestinal microbiome and its association with the control of pathogens in broiler chicken production: a review. Poult. Sci 97:1006-1021.

COLIN, B., 2012. The bacterium, Lysinibacillus sphaericus, as an insect pathogen. Journal of Invertebrate Pathology 109 (1): 1-10.

DANDACHI, I., SOKHN, E. S., DAHDOUH, E. A., AZAR, E., EL-BAZZAL, B., ROLAIN, J. AND DAOUD, Z., 2018. Prevalence and Characterization of Multi-Drug-Resistant Gram-Negative Bacilli Isolated From Lebanese Poultry: A Nationwide Study. Front Microbiol 9: 550.

DUC, L. H., HONG, H. A., BARBOSA, T. M., HENRIQUES, A. O. AND CUTTING, S. M., 2004. Characterisation of Bacillus probiotics available for human use. Appl. Environ. Microbiol 70:2161-2171.

FORGHANI, F., KIM, J. B. AND OH, D. H., 2014. Enterotoxigenic profiling of emetic toxin- and enterotoxin-producing Bacillus cereus, isolated from food, environmental, and clinical samples by multiplex PCR. Journal of Food Science 79: 22882293. https://doi.org/10.1111/1750-3841.12666 FSANZ 2018.

GREEN, D. H., WAKELEY, P. R., PAGE, A., BARNES, A., BACCIGALUPI, L., RICCA, E. AND CUTTING, S. M., 1999. Characterization of two Bacillus probiotics. Appl. Environ. Microbiol 65:42884291.

HAQUE, M. A., QUAN, H., ZUO, Z., KHAN, A., SIDDIQUE, N. AND HE, C., 2021. Pathogenicity of feed-borne Bacillus cereus and its implication on food safety. Agrobiological Records 3: 1-16.

HOA, N. T., BACCIGALUPI, L., HUXHAM, A., SMERTENKO, A., VAN, P. H., AMMENDOLA, S., RICCA, E. AND CUTTING, A. S., 2000. Characterization of Bacillus species used for oral bacteriotherapy and bacterioprophylaxis of gastrointestinal disorders. Appl. Environ. Microbiol 66:5241-5247.

HOLT, J. G., KRIEG, N. R. AND SNEATH, P. H. A., 1994. Bergey's manual of determinative bacteriology, $9^{\text {th }}$ edn. Baltimore: Williams and W Wilkins.

HÖLZEL, C. S., TETENS, J. L. AND SCHWAIGER, K., 2018. Unraveling the Role of Vegetables in Spreading Antimicrobial-Resistant Bacteria: A Need for Quantitative Risk Assessment. Foodborne Pathog Dis 15(11):671-688.

HOSSAIN, M. T., SIDDIQU, M. P., HOSSAIN, F. M. A., ZINNAH, M. A., HOSSAI, M. M., ALAM, M. K., RAHMAN, M. T. AND CHOUDHURY, K. A., 2008. Isolation, identification, toxin profile and antibiogram of Escherichia coli isolated from broilers and layers in mymensingh district of Bangladesh. Bangl. J. Vet. Med 6 (1): 01-05.

IFTIKHAR, A., AKIRA, Y., ATSUSHI, Y. AND TORU, F., 2007. Proposal of Lysinibacillus boron tolerant gen. nov. sp. nov., and transfer of Bacillus fusiformis to Lysinibacillus fusiformis comb. Nov. and Bacillus sphaericus to Lysinibacillus sphaericus comb. Nov". International Journal of Systematic and Evolutionary Microbiology 57 (5): 1117-1125.

JENSEN, G. B., HANSEN, B. M., EILENBERG, J. AND MAHILLON, J., 2003. The hidden lifestyles of Bacillus cereus and relatives. Environ Microbiol 5: 631-640.

MARTínEZ, S. A. AND DUSSÁN, J., 2017. "Lysinibacillus sphaericus plant growth promoter bacteria and lead phytoremediation enhancer with Canavalia ensiformis," Environmental Progress \& Sustainable Energy, vol. 37, no. 1, pp. 276-282.

MAY, F. J., POLKINGHORNE, B. G. AND FEARNLEY, E. J., 2016. Epidemiology of bacterial toxin-mediated food-borne gastroenteritis outbreaks in Australia, 2001 to 2013. Commun Dis Intell Q Rep. 40(4):E460-E469.

NGUYEN, A. T. AND TALLENT, S. M., 2019. Screening food for Bacillus cereus toxins using whole-genome sequencing. Food Microbiol 78:164-170.

NICHOLSON, W. L. AND SETLOW, P., 1990. Sporulation, germination and outgrowth, p. 391-450. In C. R. Harwood and S. M. Cutting (ed.), Molecular biological methods for Bacillus. John Wiley \& Sons Ltd., Chichester, United Kingdom.

O'DRISCOLL, J., 1977. Venereal Infection in thoroughbreds with bacillus Proteus mirabilis. Veterinary Record 100: 534.

PATTERSON, J. A. AND BURKHOLDER, K. M., 2003. Application of prebiotics and probiotics in poultry production. Poult. Sci 82:627-631.

PINE, J. H., RITCHER, W. R. AND ESTERLY, J. R., 1973. Bacterial Pneumonia: ultrastructural, autoradiographic and histochemical observations. American Journal of Pathology 73: 115-124.

QUINN, P. J., MARKEY, B. K., CARTER, M. E., DONNELLY, W. J. AND LEONARD, F. C., 2002. Veterinary Microbiology and Microbial Disease.1st Edition.Cornwall, Great Britain: Blackwell Science Ltd. 43-122. 
RANJITKAR, S., LAWLEY, B., TANNOCK, G. AND ENGBERG, R. M., 2016. Bacterial Succession in the Broiler Gastrointestinal Tract Appl Environ Microbiol 82(8): 2399-2410.

ROY, S. R., RAHMAN, M. B., HASSAN, J. AND NAZIR, N.H., 2012. Isolation and Identification of Bacterial Flora from Internal Organs of Broiler and Their Antibiogram Studies. Microbes and Health $1(2): 72-75$.

SALYERS, A. A. AND WHITT, D. D., 2002. Bacterial pathogenesis: a molecular approach, ASM Press, Washington DC.

STECHER, B. AND HARDT, W., 2008. The role of microbiota in infectious disease. Trends Microbiol; 16 : 107-114.

THEIN, C. C., TRINIDAD, R. M. AND PAVLIN, B. I., 2010. A large food borne outbreak on a small Pacific island. Pac Health Dialog 16(1):75-80.

WEI, S., MORRISON, M. AND YU, Z., 2013. Bacterial census of poultry intestinal microbiome. Poult Sci Sympos 92:671-83.

WILSON, G.S. AND MILES, A., 1975. Principles of Bacteriology, virology and immunity.6th Edition. London: Edward Arnold Ltd 887-900.
How to cite this article:

Eman M. Desouky, Heba N. Deif and Jakeen

K. Eljakee, 2021. Isolation and Identification of the most common Bacteria Isolated from Intestine of Broiler Chickens in Egypt. Journal of Applied Veterinary Sciences, 6 (4): $23-27$.

DOI:https://dx.doi.org/10.21608/javs.2021.87134.1092 